\title{
Philosophical Quest and Growing up Motif in Ambiguous Adventure by Chiekh Hamidou Kane and Dead Men's Path by Chinua Achebe
}

\author{
Chigbu Andrew Chigbu, Ike Doris Ann Chinweudo, Chibuzo Martin Onunkwo* \\ Department of English and Literary Studies, University of Nigeria, Nsukka Enugu State, Nigeria
}

Corresponding Author: Chibuzo Martin Onunkwo, E-mail: Chibuzo.onunkwo@unn.edu.ng

\section{ARTICLE INFO}

Article history

Received: July 14, 2017

Accepted: September 14, 2018

Published: December 01, 2018

Volume: 7 Issue: 7

Advance access: October 2018

Special Issue on Language \&

Literature

Conflicts of interest: None

Funding: None

\begin{abstract}
In literary tradition, some of the innovative and formative trends that characterise production and consumption of mimetic art in most third World countries of Africa focuses extensively on formation of the personal agents- specifically, the protagonist.This phenomenon has characterised most of the $21^{\text {st }}$ Century texts and classed them under the literary sub-genre known as Bildungsroman. Bildungsroman is viewed primarily as a nineteenth-century literary phenomenon and the term is used so loosely and broadly that any novel - and even an epic poem like Iliad and Odyssey by Homer - that include elements of coming-of-age narrative might be labelled as a "Bildungsroman".It is true that the type of novel commonly referred to as the "Bildungsroman" flourished in British literature in Victorian age, and was extremely popular among the realist writers. This accounts for early British publication of Charles Dickens, Charlotte Brontë, George Eliot and others who employed the pattern, for their novels of character formation into the fictional model of the Bildungsroman literature; a genre that consists of the literary treatment of the process of development and formation of a character in relation to society. As it were, the variety of Philosophical Bildungsroman is an advance variant of Bildung that offers the necessary extension and complexity to the phenomenological literary concern of Martin Heidegger, who posits the philosophical experience of the individual as the "Dasine". Dasien is Heidegger's philosophical concept which means "being there". As a concept in existential philosophy, Heidegger employs it to explain the very concept of personhood. The philosophical quest in this case is attained through the process of "unconcealment" meaning "the disclosure of truth". Meanwhile, in rethinking Ambiguous Adventure and Dead Men's Path as typical Bildung texts, the real unconcealment will be extricated from the "thingly character or the constitutive elements" (Poetry Language Thought, 54)of the protagonists, so as to determine, and have a clear vision and beauty of a (realist) representation of these agent (s) maturing in relation to the modern demands of society woven in universalistic model of growth and development via social background. Thus, "beauty becomes one way in which truth occurs as unconcealdness" (The Origin of the Work of Art, 55). This is because in philosophical Bildung, the attainment of successful maturation remains the object of our inquiry and concern, and this is framed within a large-scale diachronic model of human existence; who engages in the act of "thinking a thought, this kind of thinking concerns the relation of being to man" (Letter to Humanism, 1) and remains the prototype of a true Bildung character and texts understudy, namely: Ambiguous Adventure and The Dead Men's Path. Therefore, this paper opens up a new pattern of thought by investigating philosophical quest and growing up motif in this two novels using Heidegger's notion of dasien and unconcealment.
\end{abstract}

Key words: PhilosophicalBildungsroman, Dasien, Unconcealment, Formation, Will to Power.

\section{INTRODUCTION}

In literary study, the novel of formation also called Bildungsroman or the coming -of-age story is a literary sub-genre that focuses on the psychological, educational and moral growth of the protagonist from childhood to maturation, and in which character change/transformation is important. The emerging development covers the creative hiatus of colonial and postcolonial experience that dominate African literary canon in late 50-60s. Thus, the contemporary writers and critics have been eruditely locating the growing up motif/ coming of age ethos to emphasize that growth and development are universal human phenomena.

Chiekh Hamidou's Ambiguous Adventure and Chinua Achebe's Dead Men's Path, are fictional texts that examine the growth and development of their protagonists. Both writers through the eye of their protagonists strive to establish the overall growth and developmental pattern of their society being in contact with European hegemony. In this regard, 
Ambiguous Adventure is both a symbolic representation of an allegorical work; depicting the growth stance of Diallobe country responding to foreign education, product of European civilisation and an autobiographical text that recounts the escapades of the writer, Chiekh Hamidou, weaved in the existential philosophy of the protagonist, Samba Diallo. According to Achebe, art does not happen in a vacuum, it must be about something beyond aesthetic to a statement of facts and value. Thus Hamidou's text shows the growth and developmental trajectory of his protagonist, Samba Diallo who grows up, a scrupulously religious lad from infancy towards his philosophical quest as a degree holder student in Paris, and the tragic demise of Samba resulting from crisis of identity.

\section{Grwoing up Motif in Ambiguous Adventure}

Bildungsroman generally has three variants: Entwicklungsroman-novel of general growth, Erziehungsroman- novel of educational development and Kunstlerroman novel of artistic representation. A critical swotting of Ambiguous Adventure locates the text within the two variants of Bildungsroman, namely Entwicklungsroman and Erziehungsroman. This is from the point that the text captures: "the philosophical dialogue between the West and African continent" and adventurous itinerary of Samba Diallo from Diallobe countryside to his subsequent education in Paris.

The text is structured into two parts: Samba's life in Koranic school in Diallobe and life in University of Paris. Positing Ambiguous Adventure as Erziehungsroman, the novel follows the ideal structural pattern of a deliberate inculcation (often by a master) of life lessons by means of a particular pedagogic structure; in Samba's case, an ascetic religious indoctrination is invoke, in place of the typical religious education (moral training) that ought to care for the soul and geared towards "self-fulfilment" of the individual. Samba frequently experienced excruciating torture in his search of spiritual fulfilment; a demand from Islamic religion which also remains inseparable from his cultural norms. Thus, Samba's quest for fulfilment is not without painstaking exertion towards the subduing of the self to a "superior being" ably represented in Thierno, his master, who he models after at all costs. In this way, Samba fulfils one of the classical definitions of Bildung that posits it as an apprenticeship novel. This will bring us to the crux of the matter- the philosophical dimension of Bildungsroman using Heidegger's concept of Daisen to explore Samba's interpretation of life/world around him in relation to "otherness", yet retaining the ontological essence of his "being" in itself. The concept of Dasien will go a long way in unveiling why the personal agent experiences a kind of fragmented self at the end of the text and some critics have suggested that Hamidou after his studies in Europe, equally returned home, a fragmented personality.

\section{PHILOSPHICAL BILDUNGSROMA IN AMBIGUOUS ADVENTURE.}

In Being and Time, Heidegger avers that "every inquiry is a seeking (Suchen), and every seeking gets guided beforehand by what is sought" (5). Right from Aristotle's Nicomache- an Ethics, Rene Descartes in his "Clear and Distinct Idea", Arthur Schopenhauer idea of "Will to Power" as that which constitutes the dynamic essence of the world, to Heidegger's concept of "Daisen", a defining feature of philosophy that glues it to literary discourse/art centres on its power to inquire into the very nature of a thing. Akwanya, argues that "to know a "thing" is to characterise and understand its properties and how it operates in a given environment" (Literature in the Light of Philosophy, 1). Thus, every philosophical thought focuses on "becoming what one is" irrespective of other verisimilar variables that may not have "universal good" as its end. In our discourse, the act of becoming takes the path of inquiry into the essence or goodness of a thing, that is, the essence of the prime elements involved in the training of a character. Hence, we acknowledge that there is a seeking and every seeking (inquiry) has an object sought after. Since training of a character is the object of our investigation, our purpose of seeking in this context must aim at some (universal applicability) and not certain particular good.

One may ask, what is it that guides seeking? The quest to seek primarily starts as a result of the fact that man is insatiable, and will always be in need to escape from the voidableness that dares his existential bearing. Aristotle argues that "man is essentially social; it has to determine what is good? What can law do to promote this good" (Ethics of Aristotle, Book1, 9). The good in question is relational to the status quo that guides and guarantees fulfilled living for an individual. From time immemorial, no other variables could guide seeking, save the light of philosophy that exudes and illumines the mind of the individual towards the "unconcealment". Unconcealment in this case is "the disclosure of truth". Thus the cardinal role of Samba is to seek the (universal paradigmatic) truth in proper bearing, mindless of the religio-cultural status quo or laws prescribed by Dillobe countrymen. Seeking in this case is a kind of soul searching adventure, where the principal agent, Samba, seeks to know and understand that, which generally characterise his becoming in a given environment. In truth he will discover the concealed, and strive to "unconceal" the mechanisms (laws) that make up his individual being, which ought to elicit self-fulfilment that is relative to "other". The notion of "Concealed" in this regard has to do with those latent cultural/non-relational elements in Samba which do not guarantee authentic becoming (that is Universal/holistic growth).

Achebe understands this when he argues that “...we must not see the role of literature only in providing latent support for things as they are, for it does also offer the kinetic energy necessary for social transition and change... for literature is also deeply concerned with change" (Hopes and Impediment, 167).The genus is at it again, he understands the need for application of situational ethics in production and consumption of literary works. It is worth saying that most African writers and critics view (African) literature as that which should preserve our cultural heritage from waning amidst our fast modernising world. Thus, they strive at all cost to preserve the status quo that characterise authentic living in traditional African society. One perhaps ought not to wonder at the dilemma and anguish that Diallobe people were thrown into in 
view of European incursion in their country. Achebe argues that Hamidou presents the "Philosophical dialogue between the West and African, where the Diallobe people-bearers of Islam in the West African Savannah are suffering the traumatic anguish of defeat by French imperial arms, and pondering what the future course of their lives should be, should they send their children to the new French school or not? They finally opt to send them but not on the admission that their own school is in any way inferior to the French nor with the aspiration that they should become like the French in due course" Achebe points that the trouble with their decision is that these children lunched into ambiguous journey with an ambivalent mandate to experience and not to become, are doomed from the start to distress and failure" (52). The long exert shows the thinking pattern and the obnoxious world view that characterise African society, where things remain as they were, and people very often are mindless of the need to grow and change with the changing world. The same myopic attitude to life was evident in Achebe's Dead Men's Path, where the village priest of Ani had a parochial view of the need to make Ndume school a viable prospect that will deliver Ndume people from their long age old superstitious believe in reincarnation. This believe impends the growth and progress of their society; for it is apparent that their traditional system is not compatible with the Westernised system of value that is resourceful in its nature. The Priest was bent on extinguishing the new school at the expense of their ancestral footpath. He argues with Mike Obi, the new Headmaster "I have heard that our ancestral footpath has recently been closed...to which Obi insists that the old should give way to new way of living, "yes, replied Obi, we cannot allow people to make a high way of our school compound" (Dead Men's Path, 2).In the two texts, there is a dialogue between too values, traditional and western values; each struggling to outlive the other.

Considering the reaction and decision of Diallobe people, "to experience but never to become", they soon forgot that any intellectual experience brings about new knowledge. Thus, Akwanya is right in saying that "art is addressed to the intellectual memory...it seeks to bring into consciousness new objects of knowledge .... an expression of their religious sensibility, for religious thoughts that underline African art may be manifested as ritual or it may be purely symbolic" (Major Themes in African Literature, 1)The trouble with Diallobe people was not simply the fear of losing their old age ethos, rather, they were unable to be engaged in an expedient thinking. They need to rethink and put away those obnoxious tendencies that either aim at good of the people or in consonance with the trend of technologized world. According to Aristotle, "every act and purpose, seems to aim at some good; and so it has been well said that the good is that at which everything aim, meaning... in all he does, man seeks some good as the end" (NicomacheanEthics Book 1). Thus Samba's growth trajectory should be guided and directed towards achieving a universal good.

In his introductory paragraph, Heidegger argues that "the essence of any action is perfecting something, that is, it unfolds something in the fullness of its essence" (Letter to Hu- manism, 1). Every action is preceded by a kind of thinking, thinking, is that which sets action forth into the openness and by so doing, throws its (thinking) essence forth into the openness of its being. Thus, thinking when taken by itself is a way of behaving, which indirectly in technical terms characterises thinking, and gives a valid explanation of expedient thinking. By implication, thinking is of various kinds, but the kind we prescribe for a true Bildung character is that which has universal applicability, and geared towards an effective and efficient outcome. Only the wise thinks, thus the act of thinking specifically belongs to the domain of philosophy "philo" "Sophia" meaning "love of wisdom". Therefore, in a true Bildung character growing up to maturity, wisdom it is that guides and directs Samba's actions and reactions above other traditional ethos that might hamper his growth trajectory.

\section{Philosophical Bildungsroma as a Way of Unconcealment in Ambiguous Adventures}

Conversely, the issue of concealed and unconcealed elements are instrumental in determining the maturative stance of a bildungsroman character. The dyad formed the matrix of a philosophical Bildung and at the same time is inseparable from each other. This is to say that there is a synthesis of action and a kind of synergic quest for the working philosophy of the protagonist's existence. We will return to this issue later. As an infant, Samba Diallo grows under the tutelage of his ascetic master, Thieron, who on discovering all the endowments in him, acclaims that Samba is a gifted soul form God. In this discourse, it is of primary importance to establish the kind of thing Theiron saw in Samba, whether they are latent concealed values that need to be unconcealed or just ordinary mechanism. As a true bildung character, his stages of development are not without excruciating physical and psychological torture, for he had to learn and memorise the holy word without mistakes. In the outset of the novel we were introduced to the kind of religious tutorship Samba have to experience under the strict observance of his master who unleashes all sorts of inhuman treatment on the poor boy for not pronouncing the holy word as he ought. The narrator recounts: " that day, Thierno had beaten him again, and yet Samba knew his scared verse, it was only a slip of tongue ... Theirno had jumped up, seized Samba Diallo on the fleshy part of his thigh and, between his thumb and index finger, had given him a long pinch" (1). Samba's voyage started off in a rudimentary religious orientation that characterise Diallobe country. His entire meaning in life is dependent on what Diallobe society and Islamic faith dictate for him, of which Samba is expected to grow and be formed in line with thesecultural and religious status quo. Thus, there is a search for true meaning of Daisen "his beingness". In the dialogue between Samba andPerrie Louis, Samba expresses his ambiguity, living as a student in a foreign land 'I don't think it is the material environment of my country that I miss,... it might be said that I see less fully here than in the country of the Diallobe. ... after all, what I regret is not my country so much as my childhood" (149). Samba's ambivalent character has its root in ruminating on former life style in Diallobe, where according to him" man is closer to death (149) and 
he feels that coming to Paris aborts such authentic living. "I have lost a privileged mode of acquaintance, in former times, the world is like my father's “dwelling: everything took me into the very essence of itself... No scholar ever had such knowledge of any thing as I had, then, of being" (Daisen). Is Samba right in his assertion of grasping the true meaning of "being" in his father's dwelling? There is no gain saying that he is right, for true living does not depend on doing what one knows how best to do, but in opening oneself to new ideas through the act of conquering and unification of values. As the case may be, what Samba lost could not explain the true meaning of Dasine as a process of "being there", living towards extinction. Hence, Heidegger's concept should be considered as a way of unveiling true living for the protagonist.

Heidegger's concept of being in relation to personhood could be interpreted as that which lives towards extinction. Also, Aristotle reminds us that "in all he does, man searches for good as the end" (5). Therefore, Philosophical Bildung demands that the agent has to steadily remain focused in ebbing voyage of transition from traditional culture to embrace the new culture, for this remains the evolving matrix in which new character is formed and shaped. Mindful of the fact that, literature generally, as a being, is a universal proclamation of philosophical truth, African writers like their European counterparts should be guided by this truth. Characteristically, to engage in any form of philosophical thought, is to focus on "becoming what one is". This act of becoming could only be explained using what Friedrich Nietzsche regards as "The Will to Power". The will to power is one of the profound and philosophical thinking of Nietzsche that captures every human drive whatsoever as an aim to power. In his explanation, "The Will to Power could be viewed as the Revaluation of all Values" (1). Nietzsche argues that the world as a whole is fundamentally composed of Centers of power exerting force against one another" (23). Various elements: people, drives, organisms are the things exerting "Will to Power". To power is to put into venture a desired and or premeditated acts. For the artist, it is the will to create, for a student, a will to think and be engaged in an expedient thought, for a spiritualist like Theirno, the will to be religious and exert religious indoctrination over the apprentices, for an imperialist (France colonial power), the will to exert hegemonic influence over the colonised and other forms of willing that characterise our existential reality. In Ambiguous Adventure, "There is an implicature of "the will"considering the incursion of foreign education in Diallobe country as well as the textual ambiguity that made the escapades of the protagonist ambiguous. It also underlines how Diallobe people think, behaves and acts in every circumstances especially responding to the movement of the imperial forces. The Most Royale Lady's homiletic and pragmatic influence properly articulates "the implication of the will to power"I will explain this in later discussion. This "Will" expresses itself through constant revaluation of value as presentedin Heidegger's Daisen, "being" that recreates itself through a rethink in the ontological nature of "being" that is geared towards eternity. Arthur Schopenhauer locates "Will to Power" as that which constitutes the dynamic es- sence of the world. It is such ceaseless and irrational force that expresses self in various form of human nature and yet remains insatiable. Writers as thinkers (philosophers) direct their Will not just to create but, to discovery of truth. Thus the "Will" for an African writers to rethink his culture in view of fast developing and technologised world, by re-educating his society to an acceptance of "self" through the creation of diachronic framed personality.

Hamidou succeed in re-education of his society through the instrumentality of a female figure - The Most Royale Lady, but not without forceful pressure. The first crisis of Diallobe people was to determine whether they should send their children to new French school which should expose and empower them to acquire modern European education, or to send them to their Koranic school where they should maintain their traditional education. But the Most Royal Lady who is also Samba's aunt, in in a homiletic, yet pragmatic manner enjoins them to give up the former in other to gain today and win back tomorrow from the imperialist: they have to send their children to the French school because they need to learn architecture for the well-being of their country, meanwhile she is not mindless of the danger of what Diallobe stands to lose "people of Dillobe I salute you, I come here to say this to you, I, The Most Royal Lady, do not like the foreign school, I detest in my opinion, nevertheless, is that we should send our children there"(45). As a deep-thinking woman, she knows the implication of sending their children to foreign school and she reminds them: "the school in which I would place our children will kill in them what today we love and rightly conserve with care. Perhaps, the very memory of us will die in them, what I am proposing is that we should agree to die in our children's hearts and that the foreigners who have defeated us should fill the place...then Peace be upon you, the people of Diallobe, The Most Royal Lady concluded" (46). Here, two unparalleled values (A\&B) are in opposition. Value A. represents the (concealed) core values that give meaning to life in Diallobe country; such as the kind of teaching obtainable at the Glowing Hearth where they "teach the children about God, and make them to forget themselves, their bodies" (34). Value B. represents the dynamic (unconcealed) western values where the children according to the master "will learn all the ways of joining wood to wood" (34). In both cases, "The Will" as a forceful energy is at work. Innovatively, the situation plunges them into soul searching for life fulfilment through the process of revaluation. In a dialectical paradigm, the master and The Most Royal Lady venture into philosophical questions and inquiry into the feature hope of Diallobe people especially, the (youths). The need to safeguard healthy and prosperous feature becomes a necessary end. "man must respond to all the questions, Civilisations an architecture of responses, its perfection like that of any dwelling houses, is measured by the comfort man feels in it...the world is becoming westernised" (68), and "Samba Diallo must go to school if that is the will of God" (70). The Glowing Heart should give way to the foreign school, symbolically represented as the "Dwelling house".

It is worth mentioning that the training Samba received as a growing young boy in the Glowing Heart could be regarded as the initial formation that sets him fit for proper 
inculcation of (western) values, this time, through reasoning as against ordinary feeling and sentiment that characterise his education in Glowing Heart. Aristotle argues that "good moral training can qualify a man to study what is noble and just" (Ethics Book 1, no. 6.). Thus, the moral training, Samba has got, makes him to arrive at the standing point or principle of action, where he should understand that reasoning is the only gate way to success as a philosophy student. Hamidoiu presents this idea in the dialogue that exists between the Knight and Lacroix. The knight offers the position of the Diallobe and Lacroix defends Western epistemology in particular, scientific rationalism as that which will save the world from ignorance and darkness.

Hamidou ventures into Heideggerian usage adopted in Holderline's poem: "In lovely blueness blooms the steeple with metal roof" (Stuttgart, 3, ) "Full of merit, yet poetically man dwells on this earth" (Poetry, Language, Thought, 211). Hamidou adopts this to portray the possibility of human existence, full of void that can only be satisfied through man's act to venture into art (poetry) as a dwelling place.... "But how is man...every man and all the time supposed to dwell poetically.our dwelling is harassed by the housing shortage, harassed by work, made insecure by hurts for gain and success" (211). Hamidou reminds us that man, to be sure merits and earns much in his dwelling, for he cultivates the growing things of the earth and takes care of its increase. The question remains, if to live is to dwell poetically?, and if to dwell is to cultivate, what kind of things supposedly could African writer and critic cultivate and build so as to earn the gain and merits? Perhaps new knowledge of building architecture, or learning how to join wood to wood, or perhaps how to fly away from earth into fantasy through by means of poetic dwelling? Precisely, what kind of building/dwelling should Diallobe people, represented in Samba, build so as to have the merits of it dwelling? Samba seems to have the answer when he says: "I am not a distinct country of the Diallobe facing a distinct Occident, and appreciating with a cool head what I must take from it and what I must leave with it by way of counterbalance, I have become the two" (150). This is a true statement of fact and a testament of a Bildung character who opens up to adapt and be accommodated to the new culture. Heidegger established the blueprint for poetic dwelling of man when he says "man is capable of dwelling only if he has already built, is building and remains disposed to build, in another way" (242). This is the quintessence, the zenith of philosophical Bildungsroman.

We recall Aristotle's argument in Nicomachean Ethics "a man who has good moral training has arrived at the standing point...but he who has neither has them nor will accept them may hear what Hesiod says: "The best is he who of himself doth known; Good too is he who listens to the wise; But he who neither knows himself nor heeds the words of others, is a useless man" (paragraph7, pg.6). For Samba to "become the two" means that he has had a form of existence though not without imperfections, yet the opportunity of his " being a philosophy student in Paris introduce and equipped him with a superior, new knowledge which aid in his proper understanding of his raison de etre, namely to be poetic. This is true since to philosophise is to be poetic, and to be poetic is to philosophise. Both are inseparable. Thus, Samba towards the end of his voyage metamorphosis from an Islamic mystic, to a great poet/philosopher whose knowledge mesmerised and produced empirical effect on his listener, Adele, "I have never been to Africa, and I should so much like to go there". She said "it seems to me that if I were there I should learn very quickly to "understand" things as you do, ... Samba was ambivalent in his reply, perhaps that should not be "right", Samba answered "it is to learn to "understand "otherwise that we are here. All of us who are not of the West, it is for that that you ought to be born here" (156). Adele, listening to Samba, privileged his intelligence to African origin, despite Samba's ambivalent reply, the authorial voce made it clear that "the West had become involved in his life..., with the thoughts on which he had been nourished every day since the first morning when he had entered the foreign school"'(156).

Heidegger's concept of Dasin is implicated in poetic dwelling. African writers and critics have a task: to understand the meaning of their "being" what they have built, building, and what to build. Growth and maturation come through this process as is the case of Samba Diallo, who has got the traditional value and his disposition to acquire new knowledge is suggestive of the fact that he is in the process of building, but this time around in another way. The same task is required of African writers and critics. This task could only be accomplished by affirming the value of African culture and philosophy. Bernth Lindfors in Politics, Culture and Literary Form reiterates Achebe's argument in The Role of the Writer in a New Nation, of what basically formed the reason why Achebe propose what to him should be the fundamental theme of African writer and the locus of his discourse: "that African people did not hear of culture for the first time from Europeans; that their societies were not mindless but frequently had a philosophy of great depth and value and beauty, that they had poetry and above all, they had dignity that many African peoples but lost during the colonial period, and it is this that they must now regain" (157). The critic concludes that the worst thing that can happen to any people is the loss of their identity and self-respect, the writer's duty is to help them regain it by showing them in human terms what happened to them, what they lost" (Role 157). At work in Achebe is "the will", but what the critic could not expressly make clear for perhaps fear of losing stand with his people, is that every culture like human language should be dynamically creative. Its essence should be determine by its wide spread and usage. Thus there is urgent need for revaluation of African values in consonant with its proper enculturation into western values so as to create a harmonious and balanced personality.

Kane got it better in his presentation of characters who accepts the fact that Western civilization cannot be resisted, that they have to be open to both values in other to create a harmonious balance. The idea, of being both open to other cultures and rooted in one's own culture, is the identity of a modern person as a prototype of the third millennium's civilization. Samba Diallo, in Ambiguous Adventure (1962), undertakes this mission and he is a "courier", whom he tries to defend in this statement: "I am not a distinct country of the Diallobé 
facing a distinct Occident, and appreciating with a cool head what I must take from it and what I must leave with it by way of counterbalance. I have become the two" (p.150).

The Most Royale Lady understands this and that must have informed her desire to speak to her country men, and place them in the right direction.

The Most Royal Lady's strategy - "to learn from them the art of convincing without being in the right" (55) - is one of the compromises of this rendez-vous to learn the secrets of the white man. Further in her discussion, she deepens her reflection on the question by adopting a metaphorical and analogical rationale while warning her people that the event has many stakes:"But people of the Diallobé" She continued after a pause, "remember our fields when the rainy season is approaching. We love our fields very much, but what do we do then? We plough them up and burn them: we kill them. In the same way, recall this: what do we do with our reserves of seed when the rain has fallen? We would like to eat them, but we bury them in the earth."Folk of the Diallobé, with the arrival of the foreigners has come the tornado which announces the great hibernation of our people. My opinion I, the Most Royal Lady - is that our best seeds and our dearest fields - those are our children. (pp. 46-7).

This female voice, whose ideas have nothing to do with feminism, is emblematic of the

Diallobé's aristocracy, which she represents, yet having been in contact with western civilization, she stands the better to re-educate her people in the right direction towards global civilisation and human development. Her status allows her to hold such a speech from which she gives the rationale behind the compromise.

Moreover, Samba Diallo, proudly appreciates the overriding influence of the Most Royal Lady in giving explanation for his need to be schooled in foreign land. "I should not have gone to the foreign school... if it had not been for her desire to find explanation for our defeat...she said to me again "go find out, among them, how one can conquer without being in the right" (152). By implication, go learn their way, master their act, with the intention of improving in what you (Diallobe) already have so as to make a significant universal input.

As Prof Dieke would often ask "is African culture a resource or an impediment"? (1). Such philosophical question demands pragmatic and expedient feedback. One would not precisely yield to either, since growth demands a synthesis of variables that form the mechanism of human being. But, in most third world countries with traditional norms that very often impede growth, we should recall Aristotle's argument in Nicomachean Ethics "a man who has good moral training has arrived at the standing point...but he who has neither has them nor will accept them may hear what Hesiod says: "The best is he who of himself doth known; Good too is he who listens to the wise; But he who neither knows himself nor heeds the words of others, is a useless man" (7, pg.6). Achebe argues that we have a past, which we all but all lost, According to Dieke the drum we beat, everybody beats theirs, it is a global dance but what makes the difference is the distinctiveness of our rhythm, positively welling up to universal effect. Hence revaluation of value is fundamental in human becoming through situational ethics. Samba at the end of his voyage turns up a mature character whose philosophical stance coincides with Heidegger's idea that to dwell is to dwell poetically. Thus it is poetry that gave meaning to Samba's existential reality. Samba's death has been misinterpreted by many scholars to mean actual death, but Samba ended up a fulfilled character, having discovered the essence of his being in the world, namely to be poetic, and he sort for the poetic knowledge in Paris and at last put his knowledge into venture through the act of philosophical adroitness. Thus the Will to Power is at work in Samba's Dasien and existential becoming, making him to fulfil the injunction of Alexander the Pope, that What the poet must express is a universal truth which we will instantly recognize as such" (Literary Criticism: From Plato to Aristotle, 107) thus, Hamido's Ambiguous Adventure following the patter of Erzechungsroman.,

\section{REFERENCES}

Achebe, Chinua.Girls at War and Other Stories. New York: Anchor Books, 1991. Print.

African Literature: An Anthology of Criticism and Theory. Ed. Jejumola Olaniyan and Ato Quayson. USA. Black Well Publishing Ltd. 2007. Print.

Amechi, N. Akwanya LiteraryCriticism: From Formal to Questions of Method. Nigeria: University of Nigeria Press, 2017. Print.

Literature in the Light of Philosophy. University of Uyo. Vol. 9, Feb, 2017.

Aristotle: Nicomachean Ethics. Trans. F.H. Peters. London: University College, Oxford. 1906. Print.

Habib, M.A.R. Literary Criticism from Plato to Present: An Introduction. United Kingdom. Wiley-Blackwell \& Sons, INC, Publication. 2011. Print.

Heidegger, Martin. Language Poetry Thought. Trans. Albert Hofstadter. New York: Harper Perennial Modern classics 2001. PDF

Letter to Humanism. Trans. Miles Groth. PDF.

Being and Time. Trans. John Macquarie\& Edward Robinson. USA. Blackwell Oxford U.K \& Cambridge. PDF.

Kane, C. H. Ambiguous Adventure. New York: Walker and Company. 1963. Print.

Major Themes in Africa Literature. Ed. Damian U. Opata and Aloysius U Ohaeghu. Nigeria: Great A.P. Express Publishers. 2000. Print.

Nietzsche, Friedrich. The Will to Power. Trans. Walter Kaufman and R.J. Hollingdale. New York. Vintage Books. 1965. Print. 